\title{
A Study on the Effect of the Energy of Consciousness Healing Treatment on Physicochemical and Thermal Properties of Vitamin $D_{3}$ (Cholecalciferol)
}

\author{
Alice Branton ${ }^{1}$, Snehasis Jana ${ }^{2, *}$ \\ ${ }^{1}$ Trivedi Global, Inc., Henderson, Nevada, USA \\ ${ }^{2}$ Trivedi Science Research Laboratory Private Limited, Bhopal, Madhya Pradesh, India
}

Email address:

publication@trivedieffect.com (S. Jana)

*Corresponding author

\section{To cite this article:}

Alice Branton, Snehasis Jana. A Study on the Effect of the Energy of Consciousness Healing Treatment on Physicochemical and Thermal Properties of Vitamin $\mathrm{D}_{3}$ (Cholecalciferol). Science Journal of Analytical Chemistry. Vol. 5, No. 4, 2017, pp. 46-55. doi: $10.11648 /$ j.sjac.20170504.11

Received: May 20, 2017; Accepted: June 6, 2017; Published: July 14, 2017

\begin{abstract}
Vitamin $\mathrm{D}_{3}$ or cholecalciferol is a secosteroid nutraceutical used for the prevention and treatment of vitamin D deficiency. The objective of this study was to investigate the impact of The Trivedi Effect ${ }^{\mathbb{R}}$ - Energy of Consciousness Healing Treatment on the physicochemical and thermal properties of cholecalciferol using PXRD, PSA, DSC, and TGA/DTG analysis. Cholecalciferol was divided into two parts, one part of cholecalciferol was considered as control (no Biofield Treatment was provided), while second part received The Trivedi Effect ${ }^{\circledR}$ - Biofield Energy Healing Treatment remotely by a renowned Biofield Energy Healer, Alice Branton. The PXRD analysis exhibited that the relative intensities of characteristic diffraction peak in the Alice's treated cholecalciferol were significantly altered from $-28.21 \%$ to $54.16 \%$ compared with the control sample. The crystallite size of the treated sample was altered from $-40.02 \%$ to $83.20 \%$ compared with the control sample. The particle size values at $d_{10}, d_{50}, d_{90}$, and $D(4,3)$ in Alice's treated sample were significantly reduced by $33.48 \%, 23.82 \%$, $18.61 \%$, and $22.08 \%$, respectively compared to the control sample. The specific surface area of treated cholecalciferol was significantly increased by $32.72 \%$ compared to the control sample. The DSC analysis demonstrated that the melting point of the treated sample was higher by $0.24 \%$ with an enhanced latent heat of fusion $(\Delta \mathrm{H})$ by $3.54 \%$ compared to the control sample. The decomposition temperature of the treated cholecalciferol was increased by $0.12 \%$ with a significant increase of the enthalpy of decomposition by $5.85 \%$ compared to the control sample. The melting temperature and $\Delta \mathrm{H}$ of a second broad endothermic peak in the treated sample were increased by $0.18 \%$ and $73.87 \%$, respectively compared to the control sample. The TGA analysis revealed that the weight loss in the treated sample was decreased compared with the control sample. The DTG analysis indicated that the maximum thermal degradation temperature of the treated cholecalciferol was increased by $3.23 \%$ compared to the control sample. Overall, the thermal analysis indicated that the thermal stability of the treated cholecalciferol was improved compared to the control sample. Thus, The Trivedi Effect ${ }^{\mathbb{B}}$ might lead to produce a polymorphic form of cholecalciferol which might have the improved solubility, bioavailability, and thermally stability as compared with the untreated sample. The Biofield Energy Treated cholecalciferol would be beneficial to design better nutraceutical and pharmaceutical formulations, which could provide better therapeutic response against vitamin D deficiency i.e. rickets, osteoporosis, cancer, diabetes mellitus, etc.
\end{abstract}

Keywords: Vitamin $\mathrm{D}_{3}$, Cholecalciferol, Biofield Energy, The Trivedi Effect ${ }^{\circledR}$, Energy of Consciousness Healing Treatment, PXRD, Particle Size, Thermal Analysis

\section{Introduction}

Vitamin $\mathrm{D}_{3}$ or cholecalciferol is a fat-soluble secosteroid having cyclopentanoperhydro-phenanthrene ring system and possess antirachitic activity. It is produced from 7dehydrocholesterol by photochemical reaction in the skin. It 
contains three double bonds which are usually responsible for the cis and trans conformation of cholecalciferol. It is air and light sensitive compound $[1,2]$. Thus, the stability of this compound is more concerned. It is one type of vitamin D which is found to be responsible for enhancement intestinal absorption of several vital minerals like calcium, zinc, magnesium, iron, and phosphate [3]. Vitamin D plays a vital role in several diseases, e.g. cancer, diabetes mellitus, rickets, osteoporosis, mental disorders, cardiovascular diseases, multiple sclerosis, infections [4-6]. Cholecalciferol is found in animal food sources, such as cod liver oil, milk, fatty fish like salmon, tuna, etc. Now-a-days vitamin D deficiency is pandemic, mostly under-diagnosed and under-treated nutritional deficiency in the world. Cholecalciferol can be used as food and dietary supplement for the prevention and treatment of vitamin D deficiency [5]. Cholecalciferol is a prohormone and is hydroxylated at position C-25 to convert 25-hydroxycholecalciferol (also known as calcidiol), which is more circulating form. Consequently, the second hydroxylation occurs at position $\mathrm{C} 1 \alpha$ to produce its biologically active form-1,25-dihydroxycholecalciferol or calcitriol [5-7]. Vitamin D toxicity i.e. hypercalcemia, polyuria, polydipsia, weakness, insomnia, mental retardation can be resultant with high dose supplementation [3].

Biofield is sometime referred as quantum energy matrix that surrounds the human body resulting from the continuous movement of the electrically charged particles (ions, cells, etc.) inside the body and it continuous discharges the electromagnetic waves in the form of bio-photons. Healing practitioners have the ability to harness the energy from the "universal energy field" and can transmit into any living or nonliving object(s) around the earth. The process, where the objects receive the biofield energy and respond into useful way is called as Biofield Energy Healing Treatment [8, 9]. Biofield Energy Healing therapy has been recognized as a Complementary and Alternative Medicine (CAM) health care approach by National Center of Complementary and Integrative Health $(\mathrm{NCCIH})$ with other therapies, medicines and practices such as yoga, Qi Gong, Tai Chi, chiropractic/osteopathic manipulation, meditation, homeopathy, acupressure, acupuncture, healing touch, hypnotherapy, movement therapy, naturopathy, Ayurvedic medicine, traditional Chinese herbs and medicines, aromatherapy, Reiki, cranial sacral therapy, etc. [10, 11]. Biofield Energy Healing Treatment (The Trivedi Effect ${ }^{\circledR}$ ) is drawing importance in several fields include material science [12], pharmaceuticals [13], nutraceuticals [14], organic compounds [15, 16], microbiology [17], agricultural [18], biotechnology [19], genetics [20], medical [21] due to its amazing ability for modification of the characteristic properties of the numerous non-living and living substances. Recently literature reported that The Trivedi Effect ${ }^{\circledR}$-Energy of Consciousness Healing Treatment has the astounding capability to alter physicochemical properties such as crystalline structure, crystallite size, particle size, surface area, and thermal stability of various nutraceuticals such as herbal medicines, minerals through introducing a new polymorph [22-26]. It is assumed that Biofield Energy Treated pharmaceutical/nutraceutical compounds would be beneficial for enhancement of their therapeutic efficacy against the diseases. The physicochemical and thermal properties etc. of a pharmaceutical solid compound play an important role in drug product performance i.e. bioavailability, therapeutic efficacy, and toxicity [27, 28]. The Energy of Consciousness Healing Treatment (The Trivedi Effect ${ }^{\mathbb{B}}$ ) might change the physicochemical and thermal properties through the possible intervention of neutrinos [29]. Thus, it was aimed to investigate the effect of The Trivedi Effect ${ }^{\circledR}$ - Energy of Consciousness Healing Treatment on the physicochemical and thermal properties of cholecalciferol using powder X-ray diffraction (PXRD), particle size analysis (PSA), differential scanning calorimetry (DSC), and thermogravimetric analysis (TGA)/ Differential thermogravimetric analysis (DTG).

\section{Materials and Methods}

\subsection{Chemicals and Reagents}

Cholecalciferol was purchased from Sigma-Aldrich, India. All other chemicals used during the experiments were of analytical grade available in India.

\subsection{Consciousness Energy Healing Treatment Strategies}

The sample of cholecalciferol was divided into two parts. One part of cholecalciferol was considered as control (no Biofield Energy Treatment was provided). Consequently, the second part of cholecalciferol was treated with The Trivedi Effect $^{(}$- Energy of Consciousness Healing Treatment remotely under standard laboratory conditions for 3 minutes and known as The Trivedi Effect ${ }^{\circledR}$ or Biofield Energy Treated sample. This Biofield Energy Treatment was provided through the healer's unique energy transmission process by the renowned Biofield Energy Healer, Alice Branton, USA to the test item. Further, the control group was treated with "sham" healer for comparison purpose. The sham healer did not have any knowledge about the Biofield Energy Treatment. After that, the Biofield Energy Treated and untreated samples were kept in sealed conditions and characterized using PXRD, PSA, DSC, and TGA/DTG techniques.

\subsection{Characterization}

\subsubsection{Powder X-ray Diffraction (PXRD) Analysis}

The PXRD analysis of cholecalciferol was performed on a PANalytical X'PERT3 powder X-ray diffractometer, UK. Diffraction of the analyte was carried out using a copper line as the source of radiation at the X-ray of wavelength of 0.154 $\mathrm{nm}$, running at $45 \mathrm{kV}$ voltage and $40 \mathrm{~mA}$ current with a scanning rate of $18.87^{\circ} /$ second over a $2 \theta$ range of $3-50^{\circ}$. The ratio of $\mathrm{K} \alpha-2$ and $\mathrm{K} \alpha-1$ in this instrument was $0.5(\mathrm{k}$, equipment constant). The data was collected in the form of a

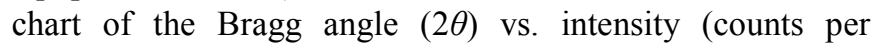
second), and a detailed table containing information on peak 
intensity counts, $d$ value $(\AA)$, relative intensity (\%), full width half maximum $(\mathrm{FWHM})\left({ }^{\circ} 2 \theta\right)$, area $\left(\right.$ cts $\left.^{* \circ} 2 \theta\right)$ using X'pert data collector and X'pert high score plus processing software. The crystallite size $(G)$ was calculated from the Scherrer equation following the literature [22-24, 30]. The crystallite size $(\mathrm{G})$ was calculated by using the following equation 1:

$$
\mathrm{G}=\mathrm{k} \lambda /(\mathrm{b} \operatorname{Cos} \theta)
$$

Where, $\mathrm{k}$ is the equipment constant $(0.5), \lambda$ is the $\mathrm{X}$-ray wavelength $(0.154 \mathrm{~nm}) ; \mathrm{b}$ in radians is the full-width at half of the peaks and $\theta$ the corresponding Bragg angle.

Percent change in crystallite size $(G)$ of cholecalciferol was calculated using following equation 2 :

$\%$ change in crystallite size $=\frac{\left[\mathrm{G}_{\text {Treated }}-\mathrm{G}_{\text {Control }}\right]}{\mathrm{G}_{\text {Control }}} \times 100$

Where, $G_{\text {Control }}$ and $G_{\text {Treated }}$ are the crystallite size of the control and Biofield Energy Treated samples, respectively.

\subsubsection{Particle Size Analysis (PSA)}

The particle size analysis of cholecalciferol was conducted on Malvern Mastersizer 3000, UK with a detection range between $0.01 \mu \mathrm{m}$ to $3000 \mu \mathrm{m}$ using wet method [22-24]. The sample unit (Hydro MV) was filled with a dispersant medium (Light liquid paraffin oil) and operated the stirrer at 2500 $\mathrm{rpm}$. Refractive index values for dispersant and samples were 0.0 and 1.47. The measurement was taken twice after reaching obscuration in between $10 \%$ and $20 \%$ and the average was taken of two measurements. Consequently, PSA analysis of cholecalciferol was repeated for three times to obtain the average particle size distribution. $d_{10} \mu \mathrm{m}, d_{50} \mu \mathrm{m}$, and $\mathrm{d}_{90} \mu \mathrm{m}$ represent particle diameter corresponding to $10 \%$, $50 \%$, and $90 \%$ of the cumulative distribution. $\mathrm{D}(4,3)$ represents the average mass-volume diameter and SSA is the specific surface area $\left(\mathrm{m}^{2} / \mathrm{Kg}\right)$. The calculations were done by using software Mastersizer V3.50.

The percent change in particle size (d) for at below $10 \%$ level $\left(\mathrm{d}_{10}\right), 50 \%$ level $\left(\mathrm{d}_{50}\right)$, and $90 \%$ level $\left(\mathrm{d}_{90}\right)$ was calculated using following equation 3 :

$$
\% \text { change in particle size }=\frac{\left[\mathrm{d}_{\text {Treated }}-\mathrm{d}_{\text {Control }}\right]}{\mathrm{d}_{\text {Control }}} \times 100
$$

Where, $d_{\text {Control }}$ and $d_{\text {Treated }}$ are the particle size $(\mu \mathrm{m})$ for at below $10 \%$ level $\left(\mathrm{d}_{10}\right), 50 \%$ level $\left(\mathrm{d}_{50}\right)$, and $90 \%$ level $\left(\mathrm{d}_{90}\right)$ of the control and Biofield Energy Treated samples, respectively.

Percent change in surface area (S) was calculated using following equation 4 :

$$
\% \text { change in surface area }=\frac{\left[\mathrm{S}_{\text {Treated }}-\mathrm{S}_{\text {Control }}\right]}{\mathrm{S}_{\text {Control }}} \times 100
$$

Where, $S_{\text {Control }}$ and $S_{\text {Treated }}$ are the surface area of the control and Biofield Energy Treated cholecalciferol, respectively.

\subsubsection{Differential Scanning Calorimetry (DSC)}

The DSC thermogram of cholecalciferol was achieved in a DSC Q2000 differential scanning calorimeter, USA under dynamic nitrogen atmosphere with flow rate of $50 \mathrm{~mL} / \mathrm{min}$ with a sample mass of $2.72 \mathrm{mg}$ using aluminum pan at a heating rate of $10{ }^{\circ} \mathrm{C} / \mathrm{min}$ from $30^{\circ} \mathrm{C}$ to $400^{\circ} \mathrm{C}$ [22-24]. The $\%$ change in melting point $(\mathrm{T})$ was calculated using following equation 5 :

$\%$ change in melting point $=\frac{\left[\mathrm{T}_{\text {Treated }}-\mathrm{T}_{\text {Control }}\right]}{\mathrm{T}_{\text {Control }}} \times 100$

Where, $\mathrm{T}_{\text {Control }}$ and $\mathrm{T}_{\text {Treated }}$ are the melting point of the control and treated samples, respectively.

Percent change in the latent heat of fusion $(\Delta \mathrm{H})$ was calculated using following equation 6 :

$$
\% \text { change in latent heat of fusion }=\frac{\left[\Delta \mathrm{H}_{\text {Treated }}-\Delta \mathrm{H}_{\text {Control }}\right]}{\Delta \mathrm{H}_{\text {Control }}} \times 100
$$

Where, $\Delta \mathrm{H}_{\text {Control }}$ and $\Delta \mathrm{H}_{\text {Treated }}$ are the latent heat of fusion of the control and treated cholecalciferol, respectively.

\subsubsection{Thermal Gravimetric Analysis (TGA) / Differential Thermogravimetric Analysis (DTG)}

TGA/DTG thermograms of cholecalciferol were obtained in a TGA Q500 themoanalyzer apparatus, USA under dynamic nitrogen atmosphere $(50 \mathrm{~mL} / \mathrm{min})$ using a platinum crucible at a heating rate of $10{ }^{\circ} \mathrm{C} / \mathrm{min}$ from $25^{\circ} \mathrm{C}$ to $900^{\circ} \mathrm{C}$ with the recent literature [22-24]. The \% change in weight loss (W) was calculated using following equation 7 :

$$
\% \text { change in weight loss }=\frac{\left[\mathrm{w}_{\text {Treated }}-\mathrm{w}_{\text {Control }}\right]}{\mathrm{w}_{\text {Control }}} \times 100
$$

Where, $\mathrm{W}_{\text {Control }}$ and $\mathrm{W}_{\text {Treated }}$ are the weight loss of the control and Biofield Energy Treated cholecalciferol, respectively.

The $\%$ change in maximum thermal degradation temperature $\left(\mathrm{T}_{\max }\right)(\mathrm{M})$ was calculated using following equation 8 :

$$
\% \text { change in } \mathrm{T}_{\max }(\mathrm{M})=\frac{\left[\mathrm{M}_{\text {Treated }}-\mathrm{M}_{\text {Control }}\right]}{\mathrm{M}_{\text {Control }}} \times 100
$$

Where, $\mathrm{M}_{\text {Control }}$ and $\mathrm{M}_{\text {Treated }}$ are the $\mathrm{T}_{\max }$ values of the control and Biofield Energy Treated cholecalciferol, respectively.

\section{Results and Discussion}

\subsection{Powder X-ray Diffraction (PXRD) Analysis}

The sharp and intense peaks in PXRD diffractograms of the control and Biofield Energy Treated cholecalciferol (Figure 1) revealed that both the samples were crystalline in nature. The values of the Bragg angle as shown in the Figure 1 and other PXRD data like d-spacing of the control sample were matched with the reported values for cholecalciferol [1]. 

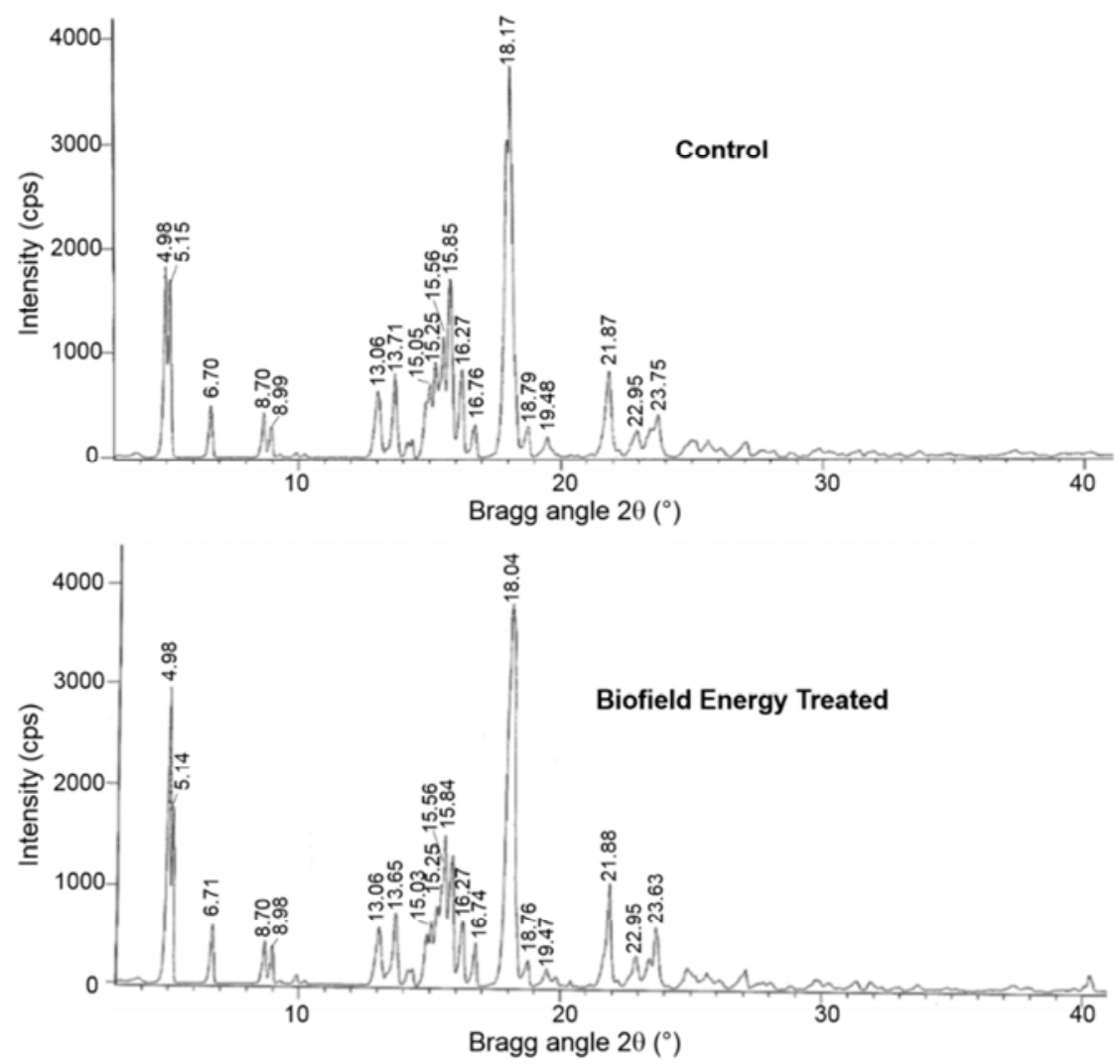

Figure 1. PXRD diffractograms of the control and Biofield Energy Treated cholecalciferol.

The PXRD diffractograms of the control and Biofield Energy Treated samples showed highest peak intensity $(100 \%)$ at Bragg's angle (20) equal to $18.0^{\circ}$ (Table 1 , entry 14). Besides, the relative intensities of the PXRD peaks at $2 \theta$ equal to $5.0^{\circ}, 5.1^{\circ}, 6.7^{\circ}, 9.0^{\circ}, 15.6^{\circ}, 16.7^{\circ}, 21.9^{\circ}, 23.0^{\circ}$, and $23.7^{\circ}$ (Table 1 , entry $1-3,5,10,13$, and 17-19) in the Biofield Energy Treated sample were significantly increased from
$2.68 \%$ to $54.16 \%$ compared to the control sample. Consequently, the relative intensities of the PXRD peaks at $2 \theta$ equal to $8.7^{\circ}, 13.1^{\circ}, 13.7^{\circ}, 15.0^{\circ}, 15.3^{\circ}, 15.8^{\circ}, 16.3^{\circ}$, $18.8^{\circ}$, and $19.5^{\circ}$ (Table 1 , entry $4,6-9,11,12,15$, and 16) in the Biofield Energy Treated sample were significantly decreased from $0.98 \%$ to $28.21 \%$ compared to the control sample.

Table 1. PXRD data for the control and Biofield Energy Treated cholecalciferol.

\begin{tabular}{|c|c|c|c|c|c|c|c|}
\hline \multirow{2}{*}{ Entry No. } & \multirow{2}{*}{ Bragg angle $\left({ }^{\circ} 2 \theta\right)$} & \multicolumn{3}{|c|}{ Relative Intensity (\%) } & \multicolumn{3}{|c|}{ Crystallite size (G, nm) } \\
\hline & & Control & Treated & $\%$ change $^{a}$ & Control & Treated & $\%$ change $^{b}$ \\
\hline 1 & 5.0 & 49.87 & 76.88 & 54.16 & 49.22 & 38.28 & -22.24 \\
\hline 2 & 5.1 & 42.52 & 43.66 & 2.68 & 49.23 & 49.23 & 0.00 \\
\hline 3 & 6.7 & 12.09 & 13.24 & 9.51 & 43.10 & 38.31 & -11.12 \\
\hline 4 & 8.7 & 11.17 & 11.06 & -0.98 & 43.15 & 31.37 & -27.29 \\
\hline 5 & 9.0 & 7.79 & 9.97 & 27.98 & 43.16 & 57.49 & 33.20 \\
\hline 6 & 13.1 & 17.19 & 15.18 & -11.69 & 24.74 & 31.49 & 27.29 \\
\hline 7 & 13.7 & 21.32 & 18.72 & -12.20 & 43.34 & 34.66 & -20.02 \\
\hline 8 & 15.0 & 18.73 & 16.76 & -10.52 & 49.61 & 69.37 & 39.84 \\
\hline 9 & 15.3 & 24.46 & 20.93 & -14.43 & 43.41 & 57.82 & 33.20 \\
\hline 10 & 15.6 & 31.03 & 39.31 & 26.68 & 57.84 & 57.84 & 0.00 \\
\hline 11 & 15.8 & 41.98 & 32.18 & -23.34 & 31.58 & 38.61 & 22.24 \\
\hline 12 & 16.3 & 21.09 & 15.14 & -28.21 & 38.63 & 23.17 & -40.02 \\
\hline 13 & 16.7 & 7.96 & 11.29 & 41.83 & 34.79 & 38.65 & 11.12 \\
\hline 14 & 18.0 & 100.00 & 100.00 & 0.00 & 69.65 & 69.64 & -0.02 \\
\hline 15 & 18.8 & 7.35 & 6.73 & -8.44 & 31.71 & 34.88 & 10.00 \\
\hline 16 & 19.5 & 5.27 & 4.73 & -10.25 & 31.74 & 58.15 & 83.20 \\
\hline 17 & 21.9 & 21.91 & 27.66 & 26.24 & 35.05 & 50.09 & 42.91 \\
\hline 18 & 23.0 & 6.67 & 7.72 & 15.74 & 43.91 & 50.19 & 14.30 \\
\hline 19 & 23.7 & 10.61 & 15.38 & 44.96 & 39.08 & 48.05 & 22.94 \\
\hline
\end{tabular}

${ }^{a}$ denotes the percentage change in the relative intensity of Biofield Energy Treated sample with respect to the control sample, ${ }^{b}$ denotes the percentage change in the crystallite size of Biofield Energy Treated sample with respect to the control sample. 
The crystallite sizes of the Biofield Energy Treated sample at $2 \theta$ equal to $5.0^{\circ}, 6.7^{\circ}, 8.7^{\circ}, 13.7^{\circ}$, and $16.3^{\circ}$ (Table 1, entry 1, 3, 4, 7, and 12) were significantly decreased from $11.12 \%$ to $40.02 \%$ with respect to the control sample. Consequently, the crystallite sizes of the control and Biofield Energy Treated cholecalciferol at $2 \theta$ equal to $5.1^{\circ}, 15.6^{\circ}$, and $18.0^{\circ}$ (Table 1 , entry 2,10 , and 14) remained unaltered. Furthermore, at position $2 \theta$ equal to $9.0^{\circ}, 13.1^{\circ}, 15.0^{\circ}, 15.3^{\circ}, 15.8^{\circ}, 16.7^{\circ}, 18.8^{\circ}, 19.5^{\circ}, 21.9^{\circ}$, $23.0^{\circ}$, and $23.7^{\circ}$ (Table 1 , entry $5,6,8,9,11,13$, and 15$19)$, the crystallite sizes of the Biofield Energy Treated sample were significantly increased in the range of $10.00 \%$ to $83.20 \%$ compared with the control sample. The significant changes in the crystallite size and relative intensities indicated that the crystal morphology of the Biofield Energy Treated cholecalciferol was modified compared to the control sample. The scientific literature reported that Biofield Energy Treatment has the significant capability to introduce a polymorph by modifying crystal morphology of the pharmaceuticals and nutraceuticals through altering the relative intensities and crystallite size of the diffraction peaks [22-24, 31]. Thus, The Trivedi Effect $^{\circledR}$ - Energy of Consciousness Healing Treatment probably introduced a polymorphic form through the energy transferred into the cholecalciferol. Polymorphic forms of pharmaceuticals have the significant effects on the drug performance, such as bioavailability, therapeutic efficacy, and toxicity, because of their thermodynamic and physicochemical properties like melting point, energy, stability, and especially solubility, are different (probably improvement) from the original form [31-33]. Thus, it can be predicted that Alice's Biofield Energy Treatment could be a very suitable technique for the production of novel crystal polymorph of cholecalciferol that would offer an improvement on its therapeutic performance.

\subsection{Particle Size Analysis (PSA)}

The particle size of both the control and Biofield Energy Treated cholecalciferol was evaluated and presented in Table 2. The particle size distribution of the control cholecalciferol was observed at $\mathrm{d}_{10}=133.01 \mu \mathrm{m}, \mathrm{d}_{50}=$ $402.82 \mu \mathrm{m}, \mathrm{d}_{90}=803.81 \mu \mathrm{m}$, and $\mathrm{D}(4,3)=439.50 \mu \mathrm{m}$. Consequently, the particle size distribution of the Biofield Energy Treated cholecalciferol was found at $\mathrm{d}_{10}=88.48$ $\mu \mathrm{m}, \mathrm{d}_{50}=306.88 \mu \mathrm{m}, \mathrm{d}_{90}=654.24 \mu \mathrm{m}$, and $\mathrm{D}(4,3)=$ $342.47 \mu \mathrm{m}$. The particle size values at $\mathrm{d}_{10}, \mathrm{~d}_{50}, \mathrm{~d}_{90}$, and $\mathrm{D}(4$, $3)$ in Alice's Biofield Energy Treated sample were significantly decreased by $33.48 \%, 23.82 \%, 18.61 \%$, and $22.08 \%$, respectively compared to the control sample. The specific surface area (SSA) of Biofield Energy Treated cholecalciferol $\left(42.63 \mathrm{~m}^{2} / \mathrm{Kg}\right)$ was significantly increased by $32.72 \%$ with compared to the control sample $(32.12$ $\left.\mathrm{m}^{2} / \mathrm{Kg}\right)$.

Table 2. Particle size distribution of the control and Biofield Energy Treated cholecalciferol.

\begin{tabular}{|c|c|c|c|c|c|}
\hline Parameter & $\mathrm{d}_{10}(\mu \mathrm{m})$ & $d_{50}(\mu \mathrm{m})$ & $d_{90}(\mu \mathrm{m})$ & $\mathrm{D}(4,3)(\mu \mathrm{m})$ & SSA $\left(\mathrm{m}^{2} / \mathrm{Kg}\right)$ \\
\hline Control & 133.01 & 402.82 & 803.81 & 439.50 & 32.12 \\
\hline Biofield Treated & 88.48 & 306.88 & 654.24 & 342.47 & 42.63 \\
\hline Percent change ${ }^{*}(\%)$ & -33.48 & -23.82 & -18.61 & -22.08 & 32.72 \\
\hline
\end{tabular}

$\mathrm{d}_{10}, \mathrm{~d}_{50}$, and $\mathrm{d}_{90}$ : particle diameter corresponding to $10 \%, 50 \%$, and $90 \%$ of the cumulative distribution, $\mathrm{D}(4,3)$ : the average mass-volume diameter, and SSA: the specific surface area, "denotes the percentage change in the Particle size distribution of the Biofield Energy Treated sample with respect to the control sample.

It is presumed that The Trivedi Effect ${ }^{\circledR}$ might act as an external force like ball mill for reducing the particle size of vitamin $\mathrm{D}_{3}$. Scientific literature mentioned that the reduced particle size and increased surface area of any pharmaceutical solid compound improve its absorption, dissolution rate, and bioavailability [34, 35]. Thus, it is anticipated that The Trivedi Effect ${ }^{\circledR}$ - Energy of Consciousness Healing Treated cholecalciferol might offer better bioavailability than the untreated sample.

\subsection{Differential Scanning Calorimetry (DSC) Analysis}

The DSC thermograms of the control and Biofield Energy Treated samples of cholecalciferol (Figure 2) exhibited two endothermic peaks at nearly 86 and $307^{\circ} \mathrm{C}$ and one exothermic peak at nearly $221^{\circ} \mathrm{C}$. Literature mentioned that the sharp endothermic peak at $86.30^{\circ}$ in the DSC curve is the melting point of cholecalciferol and exothermic peak at $206^{\circ} \mathrm{C}$ may be due to the decomposition of cholecalciferol [1]. The present analysis revealed that the melting point of the Biofield Energy Treated sample was higher by $0.24 \%$ compared to the control sample as shown in Table 3. After that, the latent heat of fusion $(\Delta \mathrm{H})$ of the Biofield Energy Treated cholecalciferol was decreased by $3.54 \%$ compared with the control sample. So, Biofield Energy Treated cholecalciferol required less energy in the form of $\Delta \mathrm{H}$ to undergo the whole process of melting after Alice's Biofield Energy Treatment. Consequently, the decomposition temperature and the enthalpy of decomposition in the Biofield Energy Treated cholecalciferol were increased by $0.12 \%$, and $5.85 \%$, respectively, compared with the control sample. 
Table 3. DSC data for both control and Biofield Energy Treated samples of cholecalciferol.

\begin{tabular}{lllllll}
\hline \multirow{2}{*}{ Sample } & \multicolumn{2}{l}{ Melting point/Decomposition Temperature $\left({ }^{\circ} \mathbf{C}\right)$} & \multicolumn{4}{l}{$(\mathbf{H} / \mathbf{g})$} \\
\cline { 2 - 8 } & $\mathbf{1}^{\text {st }}$ Peak & $\mathbf{2}^{\text {nd }}$ Peak & $\mathbf{3}^{\text {rd }}$ Peak & $\mathbf{1}^{\text {st }}$ Peak & $\mathbf{2}^{\text {nd }}$ Peak & $\mathbf{3}^{\text {rd }}$ Peak \\
\hline Control Sample & 86.20 & 220.93 & 307.36 & 60.76 & 147.00 & 73.39 \\
Biofield Energy Treated & 86.41 & 221.19 & 307.92 & 58.61 & 155.60 & 127.60 \\
\%Change* & 0.24 & 0.12 & 0.18 & -3.54 & 5.85 & 73.87 \\
\hline
\end{tabular}

$\Delta \mathrm{H}$ : Latent heat of fusion/Enthalpy of decomposition, "denotes the percentage change of the Biofield Energy Treated sample with respect to the control sample.
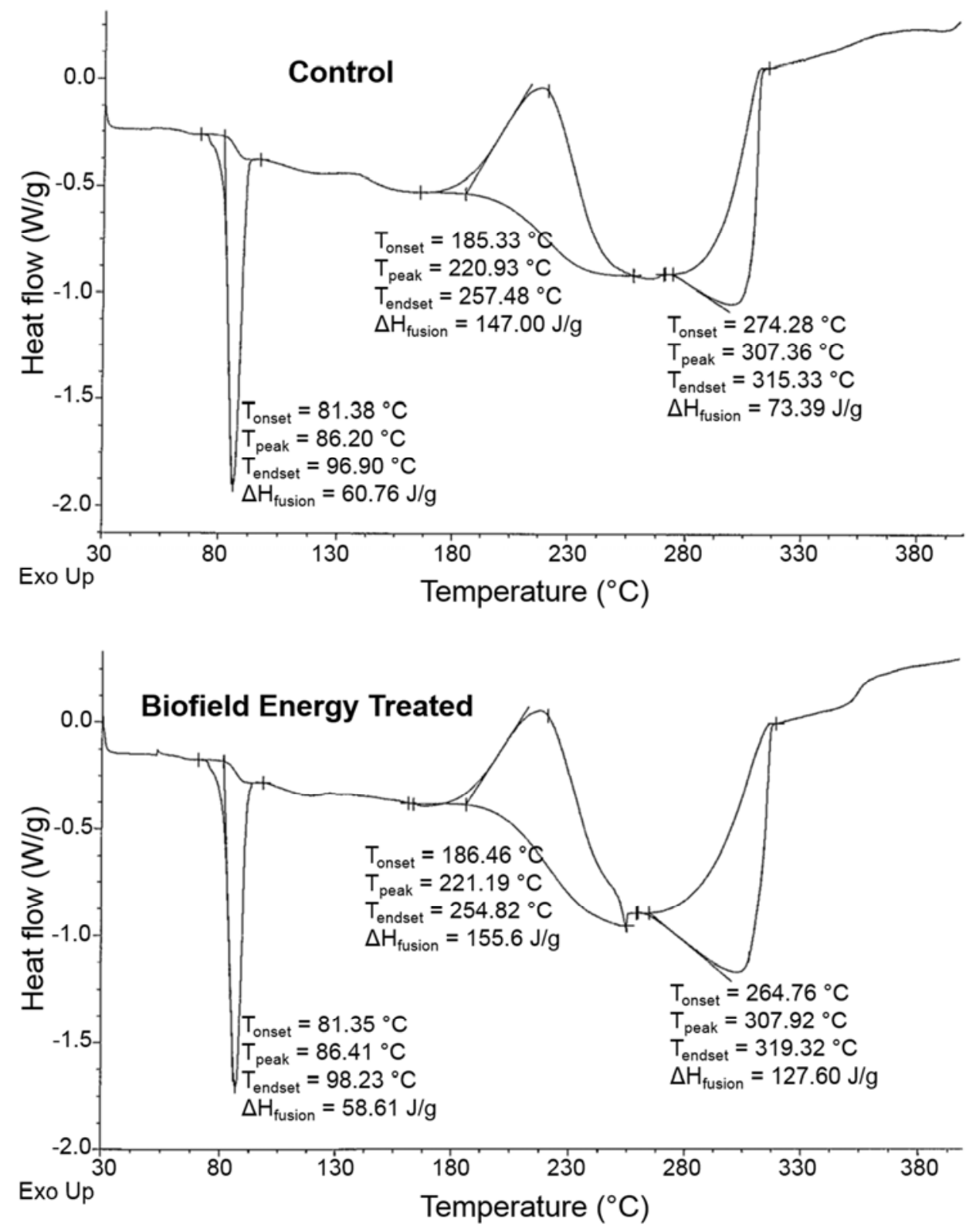

Figure 2. DSC thermograms of the control and Biofield Energy Treated cholecalciferol.

The $2^{\text {nd }}$ broad endothermic peak at nearly $307^{\circ} \mathrm{C}$ may be the slow degradation of non-volatile intermediates produced during the thermal reaction. The melting endotherm and $\Delta \mathrm{H}$ of this peak in the Biofield Energy Treated sample were increased by $0.18 \%$ and $73.87 \%$, respectively compared to the control sample. The results suggested that the thermodynamic stability of the Biofield Energy Treated sample was increased compared with the control sample (Table 3).

\subsection{Thermal Gravimetric Analysis (TGA) / Differential Thermogravimetric Analysis (DTG)}

Koshy and Beyer described that TGA curve of cholecalciferol exhibited a sharp drop in weight at $128^{\circ} \mathrm{C}$ that 
might be due to the boiling and possible splattering of the sample [1].

The TGA thermograms of the control and Biofield Energy Treated cholecalciferol showed two steps of thermal degradation (Figure 3). The percentage weight loss in Biofield Energy Treated cholecalciferol was significantly decreased by
$32.63 \%$ in the $1^{\text {st }}$ step of degradation, while the percentage weight loss in the $2^{\text {nd }}$ step degradation which showed the major weight loss was increased by $0.58 \%$ compared with the control sample (Table 4). The total weight loss in the Biofield Energy Treated cholecalciferol was reduced by $0.05 \%$ compared with the control sample (Table 4).
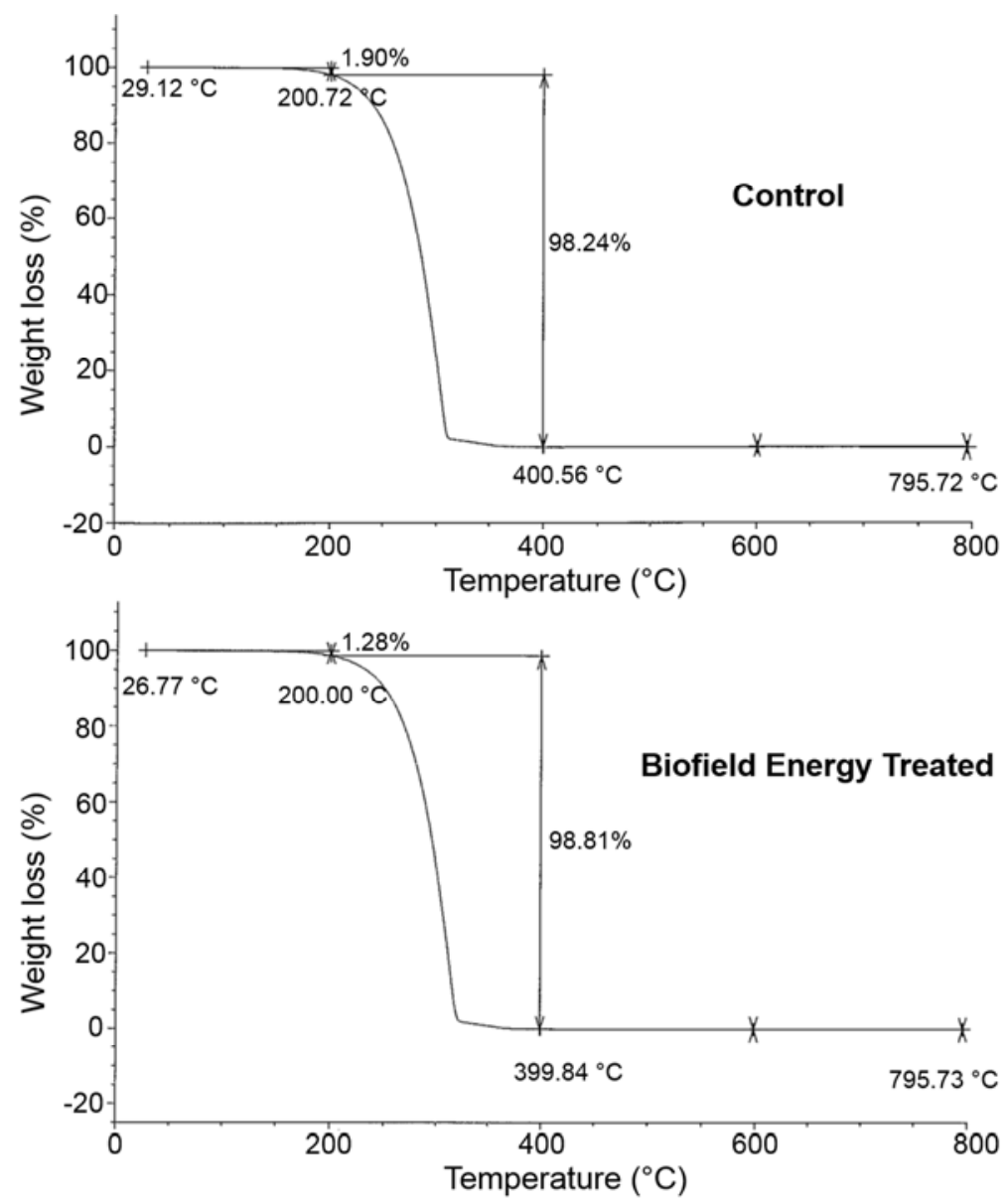

Figure 3. TGA thermograms of the control and Biofield Energy Treated cholecalciferol.

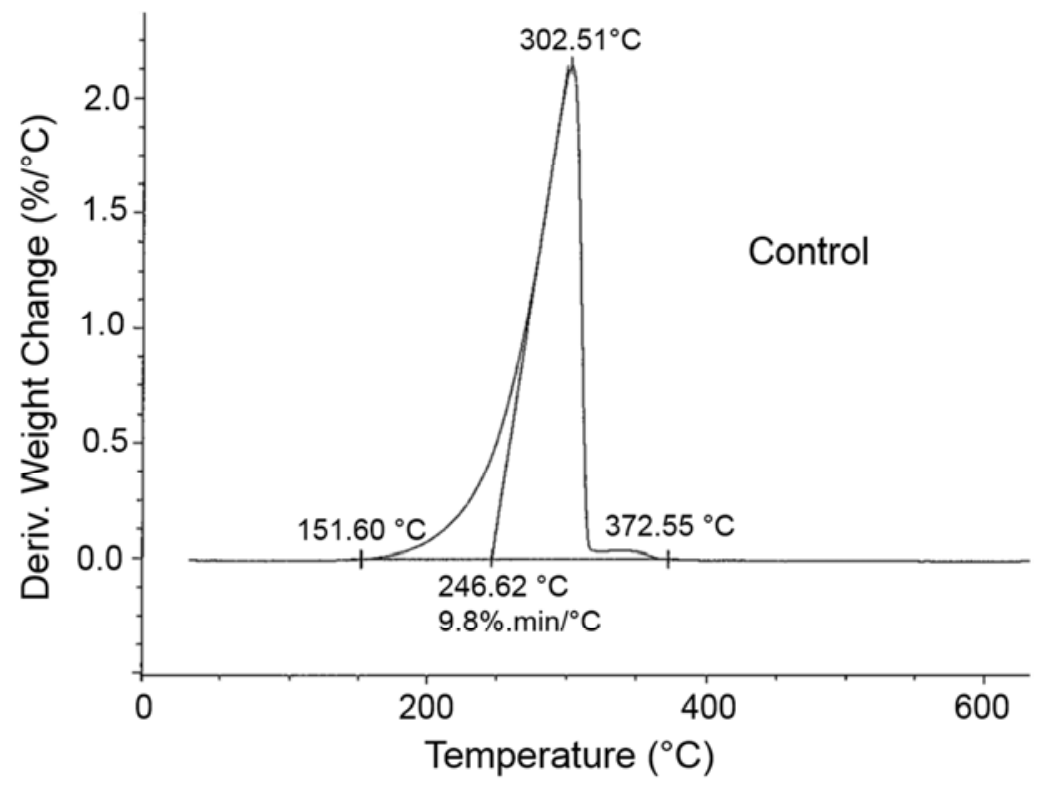




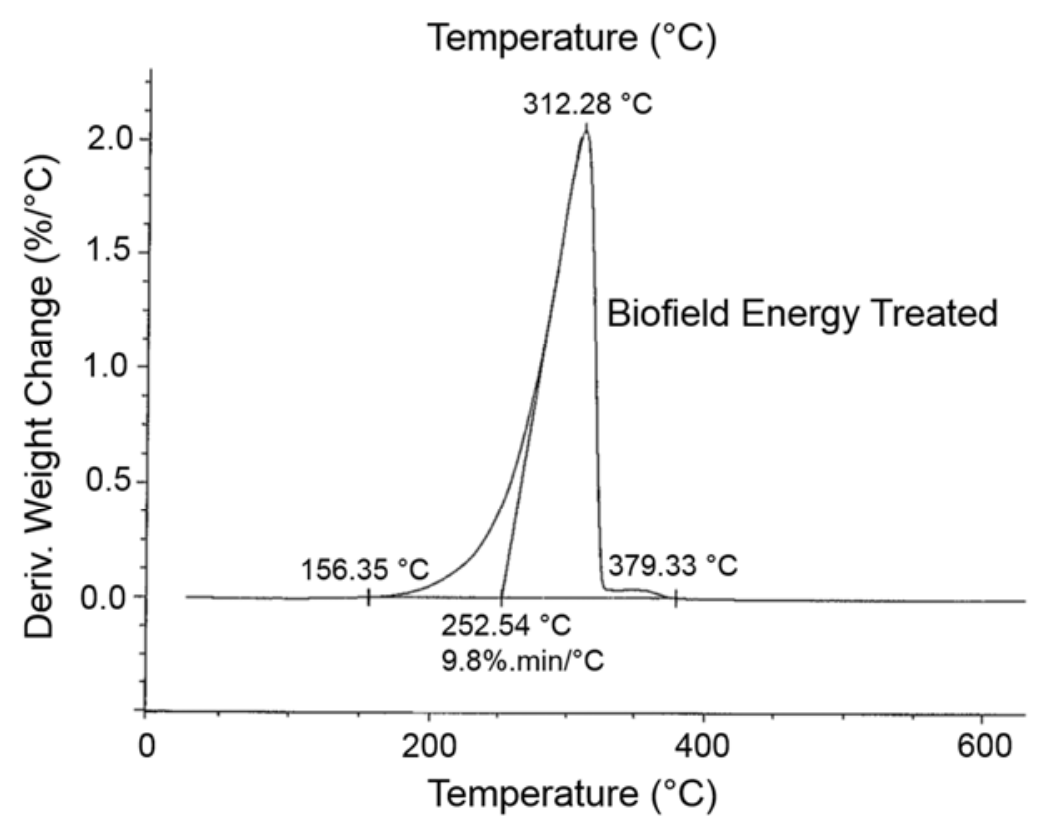

Figure 4. DTG thermograms of the control and Biofield Energy Treated cholecalciferol.

Table 4. TGA/DTG data of the control and Biofield Energy Treated samples of cholecalciferol.

\begin{tabular}{lllll}
\hline \multirow{2}{*}{ Sample } & \multicolumn{2}{l}{ TGA Weight loss (\%) } & & Total \\
\cline { 2 - 4 } & $\mathbf{1}^{\text {st }}$ step & $\mathbf{2}^{\text {nd }}$ step & $\left({ }^{\circ} \mathbf{C}\right)$ \\
\hline Control Sample & 1.90 & 98.24 & 100.14 & 302.51 \\
Biofield Energy Treated Sample & 1.28 & 98.81 & 100.09 & 312.28 \\
\% Change* & -32.63 & 0.58 & -0.05 & 3.23 \\
\hline
\end{tabular}

*denotes the percentage change of the Biofield Energy Treated sample with respect to the control sample,

$\mathrm{T}_{\max }=$ the temperature at which maximum weight loss takes place in TG or peak temperature in DTA.

The DTG thermograms of the control and Biofield Energy Treated samples (Figure 4) exhibited only one peak. The Biofield Energy Treated sample was thermally stable up to $312.28^{\circ} \mathrm{C}$, while controls sample was stable up to $302.51^{\circ} \mathrm{C}$. The maximum thermal degradation temperature $\left(\mathrm{T}_{\max }\right)$ of the Biofield Energy Treated sample was higher by $3.23 \%$ than the control sample as shown in Table 4. Overall, TGA/DTG revealed that the thermodynamic stability of the Biofield Energy Treated cholecalciferol was significantly improved compared to the control sample.

\section{Conclusions}

The present article inferred that The Trivedi Effect ${ }^{\circledR}$ Energy of Consciousness Healing Treatment exhibited the significant impact on the relative intensities and crystallite size of the characteristic diffraction peaks, particle size, surface area, and thermodynamic stability of cholecalciferol. Relative intensities of the characteristic diffraction peak in the Alice's Biofield Energy Treated cholecalciferol were significantly changed from -28.21 to $54.16 \%$ compared with the control sample. Consequently, the crystallite sizes of the Biofield Energy Treated sample was altered from $-40.02 \%$ to $83.20 \%$ compared with the control sample. The particle size values at $\mathrm{d}_{10}, \mathrm{~d}_{50}, \mathrm{~d}_{90}$, and $\mathrm{D}(4,3)$ in Alice's Biofield Energy Treated sample were significantly decreased by $33.48 \%$,
$23.82 \%, 18.61 \%$, and $22.08 \%$, respectively compared to the control sample. The specific surface area (SSA) of Biofield Energy Treated cholecalciferol was significantly increased by $32.72 \%$ with respect to the control sample. The DSC analysis demonstrated that the melting point of the Biofield Energy Treated sample was higher by $0.24 \%$ with an increased latent heat of fusion $(\Delta \mathrm{H})$ by $3.54 \%$ compared with the control sample. The decomposition temperature and the enthalpy of decomposition of the Biofield Energy Treated cholecalciferol were increased by $0.12 \%$, and $5.85 \%$, respectively compared with the control sample. The melting temperature and $\Delta \mathrm{H}$ of a broad endothermic peak in the Biofield Energy Treated sample were increased by $0.18 \%$ and $73.87 \%$, respectively compared to the control sample. The TGA thermograms of both the control and Biofield Energy Treated samples exhibited a major weight loss from $\sim 150^{\circ} \mathrm{C}$ to $350^{\circ} \mathrm{C}$. The weight loss in the Biofield Energy Treated sample was decreased compared with the control sample. The DTG analysis indicated that the $\mathrm{T}_{\max }$ of the treated cholecalciferol was increased by $3.23 \%$ compared to the control sample. Overall, the thermal analysis indicated that the thermodynamic stability of the Biofield Energy Treated cholecalciferol was significantly enhanced compared to the control sample. Thus, the Energy of Consciousness Healing Treatment (The Trivedi Effect ${ }^{\circledR}$ ) might lead to produce a polymorphic form of cholecalciferol which might have the 
improved solubility, bioavailability, and thermodynamic stability as compared with the untreated sample. The Biofield Energy Treated cholecalciferol would be very suitable to design better nutraceutical and pharmaceutical formulations which might offer better therapeutic response against vitamin $\mathrm{D}$ deficiency i.e. rickets, osteoporosis, cancer, diabetes mellitus, mental disorders, cardiovascular diseases, multiple sclerosis, infections.

\section{Acknowledgements}

The authors are grateful to GVK Biosciences Pvt. Ltd., Trivedi Science, Trivedi Global, Inc., Trivedi Testimonials, and Trivedi Master Wellness for their assistance and support during this work.

\section{References}

[1] Koshy KT, Beyer WF (1984) Vitamin $\mathrm{D}_{3}$ (Cholecalciferol) in Analytical Profiles of Drug Substances, Florey K (Ed.), Vol 13, Academic Press, Inc., Orlando, USA, pp. 656-707.

[2] Collins ED, Norman AW (2001) Vitamin D in Handbook of Vitamins, $3^{\text {rd }}$ Edn., Rucker RB, Suttie JW, McCormick DB, Machlin LJ, Marcel Dekker, Inc., New York, pp. 51-114.

[3] https://en.wikipedia.org/wiki/Vitamin_D (access on 10.05.2017).

[4] Simana E, Simian R, Portnoy S, Jaffe, A, Dekel BZ (2015) Feasibility Study -Vitamin D loading determination by FTIRATR. Information \& Control Systems76: 107-111.

[5] Ritu G, Gupta A (2014) Vitamin D Deficiency in India: Prevalence, Causalities and Interventions. Nutrients. 6: 729775 .

[6] Lawson DE, Wilson PW, Kodicek E. (1969) Metabolism of vitamin D. A new cholecalciferol metabolite, involving loss of hydrogen at $\mathrm{C}-1$, in chick intestinal nuclei. Biochem J. 115: 269-77.

[7] Mattila P, Lehikoinen K, Kiiskinen T, Piironen V (1999) Cholecalciferol and 25-hydroxycholecalciferol content of chicken egg yolk as affected by the cholecalciferol content of feed. J Agric Food Chem. 47: 4089-4092.

[8] http://www.redspiritenergyhealing.com/humanbiofield.html (accessed 10.09.2016).

[9] Nemeth L (2008) Energy and biofield therapies in practice. Beginnings 28: 4-5.

[10] Koithan M (2009) Introducing complementary and alternative therapies. J Nurse Pract 5: 18-20.

[11] Trivedi MK, Branton A, Trivedi D, Nayak G, Nykvist CD, Lavelle C, Przybylski DP, Vincent DH, Felger D, Konersman DJ, Feeney EA, Prague JA, Starodub JL, Rasdan K, Strassman KM, Soboleff L, Mayne MA, Keesee MM, Pillai PN, Ansley PC, Schmitz RD, Sodomora SM, Sethi KK, Panda P, Jana S (2017) Evaluation of the physicochemical, spectral, and thermal properties of sodium selenate treated with the Energy of Consciousness (The Trivedi Effect ${ }^{\circledR}$ ). Advances in Bioscience and Bioengineering 5: 12-21.
[12] Trivedi MK, Tallapragada RM, Branton A, Trivedi D, Nayak G, Latiyal O, Jana S (2015) Evaluation of physical and structural properties of biofield energy treated barium calcium tungsten oxide. Advances in Materials 4: 95-100.

[13] Trivedi MK, Patil S, Shettigar H, Singh R, Jana S (2015) An impact of biofield treatment on spectroscopic characterization of pharmaceutical compounds. Mod Chem Appl 3: 159.

[14] Trivedi MK, Tallapragada RM, Branton A, Trivedi D, Nayak G, Latiyal O, Jana S (2015) Potential impact of biofield treatment on atomic and physical characteristics of magnesium. Vitam Miner 3: 129.

[15] Trivedi MK, Branton A, Trivedi D, Nayak G, Singh R, Jana S (2015) Characterization of physical, thermal and spectroscopic properties of biofield energy treated $p$-phenylenediamine and $p$-toluidine. J Environ Anal Toxicol 5: 329.

[16] Trivedi MK, Branton A, Trivedi D, Nayak G, Singh R, Jana S (2015) Characterization of biofield energy treated 3chloronitrobenzene: Physical, thermal, and spectroscopic studies. J Waste Resources 5: 183.

[17] Trivedi MK, Branton A, Trivedi D, Nayak G, Mondal SC, Jana S (2015) Antimicrobial sensitivity, biochemical characteristics and biotyping of Staphylococcus saprophyticus: An impact of biofield energy treatment. J Women's Health Care 4: 271.

[18] Trivedi MK, Branton A, Trivedi D, Nayak G, Gangwar M, Jana S (2015) Agronomic characteristics, growth analysis, and yield response of biofield treated mustard, cowpea, horse gram, and groundnuts. International Journal of Genetics and Genomics 3: 74-80.

[19] Trivedi MK, Branton A, Trivedi D, Nayak G, Bairwa K, Jana S (2015) Characterization of physicochemical and spectroscopic properties of biofield energy treated bio peptone. Advances in Bioscience and Bioengineering 3: 5966.

[20] Trivedi MK, Branton A, Trivedi D, Nayak G, Gangwar M, Jana S (2015) Antibiogram and genotypic analysis using 16S rDNA after biofield treatment on Morganella morganii. Adv Tech Biol Med 3: 137.

[21] Trivedi MK, Patil S, Shettigar H, Mondal SC, Jana S (2015) The potential impact of biofield treatment on human brain tumor cells: A time-lapse video microscopy. J Integr Oncol 4: 141.

[22] Trivedi MK, Branton A, Trivedi D, Nayak G, Lee AC, Hancharuk A, Sand CM, Schnitzer DJ, Thanasi R, Meagher EM, Pyka FA, Gerber GR, Stromsnas JC, Shapiro JM, Streicher LN, Hachfeld LM, Hornung MC, Rowe PM, Henderson SJ, Benson SM, Holmlund ST, Salters SP, Panda P, Jana S (2017) investigation of physicochemical, spectral, and thermal properties of sodium selenate treated with the Energy of Consciousness (The Trivedi Effect ${ }^{\mathbb{B}}$ ). American Journal of Life Sciences 5: 27-37.

[23] Trivedi MK, Branton A, Trivedi D, Nayak G, Lee AC, Hancharuk A, Sand CM, Schnitzer DJ, Thanasi R, Meagher EM, Pyka FA, Gerber GR, Stromsnas JC, Shapiro JM, Streicher LN, Hachfeld LM, Hornung MC, Rowe PM, Henderson SJ, Benson SM, Holmlund ST, Salters SP, Panda P, Jana $S$ (2017) A comprehensive analytical evaluation of the Trivedi Effect ${ }^{\mathbb{R}}$ - Energy of Consciousness Healing Treatment on the physical, structural, and thermal properties of zinc chloride. American Journal of Applied Chemistry. 5: 7-18. 
[24] Trivedi MK, Branton A, Trivedi D, Nayak G, Plikerd WD, Surguy PL, Kock RJ, Piedad RB, Callas RP, Ansari SA, Barrett SL, Friedman S, Christie SL, Chen Liu S-M, Starling SE, Jones S, Allen SM, Wasmus SK, Benczik TA, Slade TC, Orban T, Vannes VL, Schlosser VM, Albino YSY, Panda P, Sethi KK, Jana S (2017). A systematic study of the biofield energy healing treatment on physicochemical, thermal, structural, and behavioral properties of magnesium gluconate. International Journal of Bioorganic Chemistry. 2: 135-145.

[25] Trivedi MK, Branton A, Trivedi D, Nayak G, Balmer AJ, Anagnos D, Kinney JP, Holling JM, Balmer JA, Duprey-Reed LA, Parulkar VR, Panda P, Sethi KK, Jana S (2017) Evaluation of the Energy of Consciousness Healing Treated Withania Somnifera (Ashwagandha) Root Extract Using LCMS, GC-MS, and NMR Spectroscopy, American Journal of Biomedical and Life Sciences 5(2), 16-25.

[26] Trivedi MK, Branton A, Trivedi D, Nayak G, Wellborn BD, Smith DL, Koster DA, Patric E, Singh J, Vagt KS, Callas KJ, Panda P, Sethi KK, Jana S (2017) Characterization of physical, structural, thermal, and behavioral properties of the consciousness healing treated zinc chloride. World Journal of Applied Chemistry 2: 57-66.

[27] Gupta KR, Askarkar SS, Joshi RR, Padole YF (2015) Solid state properties: Preparation and characterization. Der Pharmacia Sinica 6: 45-64.

[28] Storey RA, Ymen I (2011) Solid state characterization of Pharmaceuticals, Wiley-Blackwell, UK.
[29] Trivedi MK, Mohan TRR (2016) Biofield energy signals, energy transmission and neutrinos. American Journal of Modern Physics 5: 172-176.

[30] Langford JI, Wilson AJC (1978) Scherrer after sixty years: A survey and some new results in the determination of crystallite size. J Appl Cryst 11: 102-113.

[31] Raza K, Kumar P, Ratan S, Malik R, Arora S (2014) Polymorphism: The phenomenon affecting the performance of drugs. SOJ Pharm Pharm Sci 1: 10.

[32] Censi R, Martino PD (2015) Polymorph Impact on the Bioavailability and Stability of Poorly Soluble Drugs. Molecules 20: 18759-18776.

[33] Zhao Z, Xie M, Li Y, Chen A, Li G, Zhang J, Hu H, Wang X, Li S (2015) Formation of curcumin nanoparticles via solutionenhanced dispersion by supercritical $\mathrm{CO}_{2}$. Int J Nanomedicine 10: 3171-3181.

[34] Chereson R (2009) Bioavailability, bioequivalence, and drug selection. In: Makoid CM, Vuchetich PJ, Banakar UV (Eds) Basic pharmacokinetics ( $1^{\text {st }}$ Edn) Pharmaceutical Press, London.

[35] Mosharrof M, Nyström C (1995) The effect of particle size and shape on the surface specific dissolution rate of microsized practically insoluble drugs. Int J Pharm 122: 3547. 